\title{
The dynamic relationship between greenfield investments, cross-border M\&As, domestic investment and economic growth in Vietnam
}

\author{
Hieu Thanh Nguyen ${ }^{1} \cdot$ Hiep Ngoc Luu $^{2,3}$ (D) $\mathrm{Ngoc} \mathrm{Ha} \mathrm{Do}^{3}$
}

Received: 1 November 2019 / Accepted: 27 July 2020 / Published online: 8 August 2020

(c) The Author(s) 2020

\begin{abstract}
This paper investigates the dynamic linkages between different types of foreign direct investment (FDI), domestic investment and economic growth in Vietnam. We decompose the aggregated FDI level into its two major components: greenfield investments, and cross-border mergers and acquisitions (M\&As). The empirical results reveal that greenfield investments and cross-border M\&As exhibit different impacts on economic growth. While greenfield investments appear to complement domestic investment, which subsequently promotes long-run economic growth, cross-border M\&As exert a significant crowd-out effect and subsequently impede growth in both the short- and the long-run. These results provide important implications for policies to attract FDI in order to stimulate sustainable growth.
\end{abstract}

Keywords FDI · Greenfield investments · Cross-border M\&As · Domestic investment $\cdot$ Growth $\cdot$ SVAR

\section{Introduction}

This paper investigates the dynamic linkages between different types of foreign direct investment (FDI), domestic investment and economic growth in Vietnam. The last few decades have witnessed a meteoric rise in the economy of Vietnam.

Hiep Ngoc Luu

nhl3@st-andrews.ac.uk

1 National Economic University, Hanoi, Vietnam

2 University of St Andrews, St Andrews, UK

3 Centre for Applied Economics and Business Research, Hanoi, Vietnam 
From an isolated nation struggling with a high poverty rate, a low living standard and low production levels in the post-war years, Vietnam has transformed into one of the fastest growing countries in the region. ${ }^{1}$ The country has now become the role model for many transitional and less-developed countries with low starting points (Thoburn 2013). This "economic miracle" owes much to the adoption of the Doi Moi ("Revolution") political and economic reforms in 1986, which transformed the Vietnamese economic system from a centrally planned economy into a "socialistoriented market economy". Accordingly, the participants in the private sector (especially foreign investors) were strongly encouraged by the government, as evidenced by the enactments of various deregulations and legislation changes to remove the burdens placed on private firms. The subsequent period witnessed a surge in FDI into the country. The volume of foreign investment capital was strikingly high and reached a peak of 17.5 billion USD in 2017. As of December 2017, there were 116 nations and territories investing in Vietnam, including 26,746 projects with a total registered capital of $\$ 378.698$ billion. The total newly registered and additional capital reached USD 18.76 billion during the first 10 months of 2018, an increase of $11 \%$ in comparison with the same period in the previous year. ${ }^{2}$

Despite these impressive statistics, policymakers and economic researchers were still sceptical over the real economic benefit that FDI could actually bring to the country. A number of calls have been made for a more in-depth (i.e. Anwar and Nguyen 2010; Hoang et al. 2010) investigation into the economic implications of FDI. Unfortunately, while the FDI-growth nexus has been a traditional topic that is widely examined in the economic literature, empirical investigations to quantify the economic impact of FDI in Vietnam are still inadequate and have never reached a consensus. For example, while Vu (2008) posit that FDI can bring economic gains, Nguyen et al. (2008) detect both negative backward and forward spillovers of FDI for the service sector.

Arguably, one of the reasons for the mixed evidence documented in the existing literature can be partly traced to the heterogeneity of FDI flows. Since the aggregated FDI inflow comprises different components with divergent features, their economic implications may inherently be different (Calderón et al. 2004; Eren and Zhuang 2015). The more recent literature often separates aggregated FDI into two major components: greenfield investment and cross-border M\&A. In principle, greenfield investment involves the creation of new entities through the investment and establishment of plants, factories and human capital. Thus, it is expected to exert a direct positive impact on growth by means of physical capital accumulation and additional production capacity (Ashraf et al. 2016). On the other hand, since cross-border M\&As are merely the transfer of ownership and involve the acquisition of existing assets, they may not lead to long-term growth (Kim 2009). Nevertheless, while it may seem natural to postulate that greenfield investment brings beneficial impacts to the host country's economy and M\&As may not, not all empirical

\footnotetext{
1 The World Bank 2018. (https://www.worldbank.org/en/country/vietnam/overview).

2 Ministry of Planning and Investment. Brief on foreign direct investment of 2018. (http://www.mpi.gov. vn/en/Pages/tinbai.aspx?idTin=41941\&idcm=122).
} 
researches provide support for this proposition. For example, the studies by Calderón et al. (2004) and Ashraf et al. (2016) both document that cross-border M\&As can promote growth by enhancing productivity, whereas greenfield investment may result in a significant crowding-out effect and therefore hamper long-term growth.

Estimating the impact of different types of FDI on economic growth is an obvious challenge. Economic researches (e.g. Azman-Saini et al. 2010) have consistently emphasised that failure to model contingency effects in the relationship between FDI and growth is one of the main reasons for the mixed evidence that has been documented. A significant effort has been devoted to fostering the understanding of the contingent role of domestic investment in the FDI-growth nexus. The widespread belief is that domestic investment is an important driver of growth (Romer 1986; Lucas 1988; Firebaugh 1992; Fischer 1993). Recent empirical studies (i.e. Abu and Karim 2016; Omri and Kahouli 2014; Ahmad et al. 2018) also provide support for this proposition. In this regard, if FDI promotes (displaces) domestic investment, it may (not) be beneficial in the long run. However, the empirical evidence on how FDI affects domestic investment has again been mixed. For instance, while the study by Mutenyo and Asmah (2010) shows that domestic investment is negatively associated with FDI, Ndikumana and Verick (2008) and Tang et al. (2008) find that FDI complements domestic investment.

Research has been conducted on the relationships between FDI, domestic investment and economic growth for a long time under the assumption that FDI inflows are largely homogeneous entities. In this paper, we argue that, since FDI contains very different components, ignoring the heterogenous characteristics of different types of FDI will lead to material oversight. Until recently, only a handful of studies (i.e. Calderón et al. 2004; Balsvik and Haller 2010; Ashraf et al. 2016; Chen et al. 2017) have started to evaluate the impact of different types of FDI on domestic investments. They find that each type of FDI would impact domestic investments differently. Until now, whether and to what extent FDI can affect economic growth still remains an open empirical question.

In this paper, we attempt to close this gap in the literature and examine the dynamic relationship between different types of FDI, domestic investment and economic growth. We focus particularly on greenfield investment and cross-border M\&As when assessing FDI inflows because they are the two main types of FDI, and they compose a major portion of total FDI inflow in many developed and developing countries (Calderón et al. 2004). The United Nations also documents that total inward FDI can be measured approximately by the sum of cross-border M\&As and greenfield investment (UNCTAD 2000).

We investigate the relationship between greenfield investment, cross-border M\&As, domestic investment and economic growth in Vietnam. Vietnam emerged as a unique and ideal setting for the investigation of the growth impact of different types of FDI, both due to the sparsity of studies on the country and also due to the unique institutional system where the communist party - albeit the only party to rule the country-have still been introducing a number of regulatory reforms to liberalise the market and attract more foreign capital. Under the regulatory perspective, FDI could facilitate Vietnam's economy through direct capital formation. However, there are also increasing concerns that FDI may displace domestic investment and thus 
dampen growth in the country (Hoang et al. 2010). Collectively, whether Vietnam should either devote policy incentives for attracting more foreign capital, or whether it should give priority to promoting the domestic counterpart is an empirical question of crucial importance.

Using macroeconomic data in Vietnam over the period from 2003 to 2017, we find that cross-border M\&As and greenfield investments exhibit different impacts on domestic investment and economic growth. Specifically, we find that greenfield investments strengthen both domestic investment and growth in Vietnam. On the other hand, cross-border M\&As appear to constrain domestic investment and dampen growth in both the short- and the long-run. Therefore, the empirical findings present some implications for policymakers in Vietnam towards fostering economic growth through the development of different FDI modes of entry.

Our paper is different from other researches and thus contributes to the extant literature in a number of ways. Firstly, while many studies have examined the impact of different types of FDI on growth across countries (i.e. Ashraf and Herzer 2014), significantly less attention has been devoted to understanding the growth impact of FDI in the context of a single nation, especially in a country that is experiencing an ongoing restructuring of its political-economic environment. However, a single-country study is needed because of the heterogeneous characteristics of FDI as well as the various social-economic conditions across nations, which could impose significant constraints on the breadth and accuracy of the empirical results. In this context, and by using a rigorous empirical approach in a single-country setting, we contribute to the broad literature on the growth impact of FDI by providing a more creditable empirical result and inference. Secondly, by separately examining the impact of greenfield investment and cross-border M\&As on domestic investment, we contribute to the emerging strand of the literature that investigates the impact of different types of FDI on domestic investment (i.e. Balsvik and Haller 2010; Ashraf and Herzer 2014; Ashraf et al. 2016; Chen et al. 2017). We also go beyond this strand and show the results of how different types of FDI affect domestic investment and subsequently affect growth. More importantly, to the best of our knowledge, our study is the first to partition the total FDI and evaluate their corresponding impacts on domestic investment and economic growth in Vietnam.

The rest of this study is organised as follows: Sect. 2 discusses the relevant literature, Sect. 3 presents the data and model specification used in our analysis, and the empirical results are presented in Sects. 4 and 5 concludes.

\section{Literature review}

\subsection{The impact of FDI on economic growth}

The linkage between FDI and economic growth has often been a controversial topic. In the theoretical neoclassical growth model, FDI is illustrated as promoting growth through the accumulation of capital (Solow 1956). In this regard, FDI is expected to be more stable and less vulnerable to reversals than other types of capital flow (Levchenko and Mauro 2007; Tong and Wei 2011). Subsequently, the endogenous 
growth model demonstrates that FDI can facilitate growth, both directly by accumulating capital formation and indirectly through technological diffusion and knowledge spillovers (Caves 1974; De Mello Jr 1997; Grossman and Helpman 1991). Rodriguez-Clare (1996) provides support to this proposition and asserts that, when domestic firms absorb advanced technology and management know-how transmitted from multinational companies, their productivity increases and the host country's economy would benefit from such enhancements. Subsequently, Smarzynska Javorcik (2004) also confirm a pivotal role of FDI in promoting the positive spillover effect, such as the diffusion of ideas and the transfer of technology stemming from the interaction of foreign firms with the local economy. Research (i.e. Blomström 1991; Ashraf et al. 2016) further shows that FDI may create a necessarily competitive market that forces domestic competitors to adopt more innovative technologies and/or operate in a more efficient manner. This, in turn, could significantly contribute to economic growth. More recent empirical studies (i.e. Gunby et al. 2017; Hayat 2018) also show the evidence that FDI exerts a significant and positive impact on the economic growth of recipient countries.

Nevertheless, many other economic researchers postulate that FDI has no growth effect or could even negatively influence the economy (i.e. Driffield and Hughes 2003; Farla et al. 2016). For example, Herzer and Klasen (2008) suggest that the positive technological and knowledge spillovers proposed by the endogenous growth model may not exist in developing countries. This is because domestic firms may lack the capacity to absorb and apply the superior skills, knowledge, and advanced materials brought by foreign counterparts. In line with this proposition, Görg and Greenaway (2004) find no robust evidence to support the existence of spillovers in developing countries. Similarly, Durham (2004) does not find any direct and unmitigated positive FDI-growth nexus and argues that the impacts of FDI are contingent upon the absorptive capability of the host nation. Alfaro et al. (2004) assert that the effects of FDI on growth are contingent upon the development of the financial market. More recently, Makiela and Ouattara (2018) examine the transmission channels from FDI to growth and report a mixed evidence. Notably, they illustrate that FDI does not impact on growth through the total factor productivity enhancement channel. Even in the case where inward FDI appears to improve the overall growth potential of the host economy, this growth could be generated primarily through productivity enhancements within the foreign entities themselves, rather than through capital investment or technology and knowledge spillovers (Navaretti et al. 2006; Desbordes and Franssen 2019). Aitken and Harrison (1999) eventually show that FDI could hamper the economy in developing nations if it crowds out domestic investment. This could be a particular issue for countries that are heavily reliant on assistance from other nations, where FDI might create monopolies in the industrial sector, displacing domestic enterprises and consequently hampering the economy (Adams 2009).

A very limited number of empirical studies have been conducted on the relationship between FDI and economic growth in Vietnam. Vu et al. (2008), using sectoral data for FDI inflows into China and Vietnam from 1990 to 2004, claim that FDI has a positive impact on economic growth in both countries. Subsequently, Hoang et al. (2010) show that FDI contributes significantly to the country's stock of capital and 
thus positively impacts Vietnamese economic growth. However, when examining the interactions of FDI with domestic investment, they document a negative relationship. In other words, FDI appears to crowd out domestic investment, thus causing a reduction in Vietnam's economic growth. Subsequently, Nguyen et al. (2008) study the impacts of FDI on the technical efficiency of domestic firms and reveal that FDI does not always create positive spillovers to the technical efficiency of local enterprises. More recently, Anwar and Nguyen (2010) tested the two-way linkage between FDI and growth using a simultaneous equation model and document sufficient evidence that FDI has a direct positive and significant impact on economic growth. However, when analysing the interaction of FDI with domestic investment, they find similar results to those suggested by Hoang et al. (2010) in that, as far as domestic investment is concerned, Vietnam has not reached the minimum threshold required to gain benefits from FDI capital.

\subsection{Greenfield investment, domestic investment and economic growth}

Greenfield investment can exert a significant impact on the host country's economic growth in a number of ways. Firstly, since greenfield investment involves building everything from scratch, it can make notable contributions to capital stock for production, which is an important driver of growth. Secondly, greenfield investments could also lead to growth through the facilitation of job markets and increased competition (UNCTAD 2000). Owing to these new setting-up facilities, greenfield investment can both create new employment opportunities and also increase the number of firms in existence, thus lowering the barrier to entry. In this context, greenfield investment can be extra beneficial to the host country's economy since it could give rise to the presence of productive foreign firms and thus result in higher productivity gains. Liu and Zou (2008) examine the impact of greenfield investments on domestic firms' innovation and find that greenfield investment exerts a positive impact on innovation through both intra- and inter-industry R\&D investment. Consistent with those conjectures, Wang and Wong (2009) find that greenfield investments have a significant positive impact on economic growth in both developed and developing countries. More recently, Harms and Méon (2018) emphasise that greenfield investment has a significantly positive effect on economic growth as an entry of foreign firms in the way that greenfield investment would give rise to aggregated productivity by expanding the host country's stock of capital.

Nevertheless, some other studies find no significant, or even a negative, linkage between greenfield investment and economic growth, suggesting that greenfield investment does not necessarily foster economic growth in the host country. For example, Calderón et al. (2004) document that greenfield investment does not lead to economic growth. In a similar vein, Eren and Zhuang (2015) suggest that greenfield investment causes negative growth effects of the economy in the short run and only stimulates economic growth when the level of absorptive capability in the host country reaches a certain threshold. In this regard, the growth impacts of greenfield investment are contingent upon the availability of the host countries' absorptive capacities. In line with this proposition, some other studies propose that greenfield 
investment can lead to a significant crowding-out effect and therefore damage long-term growth. For instance, Jude (2018) empirically explores the relationship between greenfield investment and domestic investment and finds some evidence that greenfield investment exhibits a significant crowding-out effect on capital accumulation. This negative impact stems from the intensified competitive market where foreign firms, often being more superior than their domestic counterparts (Aitken and Harrison 1999), capturing market demand and then forcing domestic firms out of businesses. Similarly, Balsvik and Haller (2010) also argue that the crowding-out effects of greenfield investments may be due to the increased competition in both the product market and the labour market for qualified employees. Using panel data for 100 developing countries over the period from 2003 to 2011, Ashraf and Herzer (2014) document a similar finding that greenfield investment has a large crowdingout effect. More recently, Chen et al. (2017) further posit that the negative effects of greenfield investment on domestic investment may be attributable to the marketseeking greenfield established firms that displace their domestic competitors.

\subsection{Cross-border M\&As, domestic investment and economic growth}

The impact of cross-border M\&As on economic growth is also controversial in the economic literature. The first strand of the literature proposes that cross-border M\&As can crowd out domestic investment and subsequently hinder economic growth. One of the main reasons for this is that the presence of more foreign capital in the form of cross-border M\&As could lead to a significant, competitive pressure being placed on domestic firms. By acquiring domestic companies, foreign investors can benefit largely from the integration and the exchange of valuable resources and knowledge (i.e. scarce domestic resources and valuable local knowledge) that could grant them a fast market entry and certain competitive advantages. In these circumstances, domestic firms may not be able to compete with those foreign competitors and can eventually be forced out of business. Consistent with these propositions, Ashraf and Herzer (2014) find no evidence to suggest that M\&As can facilitate domestic investment. These findings have led recent researchers to cast doubt on the growth impact of cross-border M\&As. For example, Harms and Méon (2018) document that M\&As have no significant effect on growth, while Eren and Zhuang (2015) find that M\&As only exert positive effects on economic growth under a developed financial system.

By contrast, another strand of the literature (i.e. Danakol et al. 2017) documents the possibility that cross-border M\&As can facilitate domestic investment, improve productivity, and subsequently, facilitate economic growth. For example, Blomström and Sjöholm (1999) suggest that domestic firms can gain benefits from spillovers stemming from cross-border M\&As. Arguably, the presence of more foreign acquirers with superior technologies and skills may lead to a significant increase in industry competition that forces domestic firms to be more efficient. Calderón et al. (2004) also find that M\&As lead to the crowding-in of domestic investment. Jude (2018) documents further that, if the host country has developed financial markets (i.e. a strong banking sector), it is likely that M\&As will lead to crowding-in 
effects on domestic investment. Balsvik and Haller (2010) investigate the impact of M\&As on the productivity of domestic plants and contend that cross-border M\&As are positively associated with domestic plants' productivity, which may be due to the knowledge spillovers driven by pre-established linkages between these plants. Similarly, Ashraf et al. (2016) document a positive effect of M\&As on total factor productivity, which could arguably lead to economic growth.

\section{Data and methodology}

This section introduces the model specification in our empirical analysis. It also discusses the variables used in this study along with their sources.

\subsection{The Specification of the SVAR model}

In this paper, we employ the structural vector auto-regression (SVAR) model to study the dynamics of cross-border M\&As, greenfield investment, domestic investment and economic growth. Although the traditional vector auto-regression (VAR) model has been employed in a number of studies using time-series data, this methodology is inadequate to investigate the multivariate contemporaneous linkages between variables (Zeng et al. 2017). The SVAR model, on the other hand, can address this limitation by adding the current values of endogenous variables on the right-hand side of simultaneous equations (Zeng et al. 2017). In addition, the SVAR model can also explain the evolution of the series and analyse the dynamic impacts of different disturbances on variables. Collectively, the SVAR model appears to be the more desirable methodology to study multivariate relationships between variables in the study.

As the SVAR model requires restrictions (Magkonis and Tsopanakis 2014), in this paper, we constrain contemporaneous structural shocks by employing the recursive identification system through the Cholesky decomposition. The SVAR model is taken to be the form:

$$
A x_{t}=c_{0}+\sum_{i=1}^{n} A_{i} x_{t-i}+B \varepsilon_{t}
$$

where $n$ is the maximum lag length and $x_{t}$ denotes a $(4 \times 4)$ vector of endogenous variables. In this study, we specify an SVAR model with the following four variables: M\&A, greenfield investments, domestic investments and economic growth. The definitions and summarised statistics of the above variables will be discussed in the subsequent section. To this end, the natural logarithms of these variables, which are denoted as M\&A, greenfield investments, domestic investments and GDP, respectively, will be employed in the empirical model. A is a $(4 \times 4)$ matrix of coefficients of simultaneous relationships of the endogenous variables, $c_{0}$ is the constant, $A_{i}$ is the matrix of autoregressive coefficients, $x_{t-i}$ is a $(4 \times 1)$ vector of lagged values of endogenous variables and $\varepsilon_{t}$ is a $(4 \times 1)$ vector of uncorrelated structural innovations. 
One problem is that it is impossible to estimate the real values of components in $A$ and $A_{i}$ directly when analysing the structural model. To solve this, we follow the literature (Lee and Yue 2017) and obtain the reduced-form VAR by multiplying Eq. (1) by $A^{-1}$, which demonstrates each endogenous variable as a function of predetermined variables:

$$
x_{t}=\sum_{i=1}^{n} \sigma_{i} x_{t-i}+\mu_{t}
$$

where $\sigma_{i}$ is a $(4 \times 4)$ matrix of coefficients, $\sigma_{i}=A^{-1} A_{i}, \mu_{t}$ is $(4 \times 1)$ vector of error terms in reduced-form VAR and $\mu_{t}=A^{-1} B \varepsilon_{t}$.

Given that matrix $A$ is a lower unit triangular matrix and matrix $B$ is a diagonal matrix, they are taken to be the following forms:

$$
\left[\begin{array}{cccc}
1 & 0 & 0 & 0 \\
a_{21} & 1 & 0 & 0 \\
a_{31} & a_{32} & 1 & 0 \\
a_{41} & a_{42} & a_{43} & 1
\end{array}\right]\left[\begin{array}{c}
\mu_{t}^{M \& A} \\
\mu_{t}^{\text {Greenfield Invesments }} \\
\mu_{t}^{\text {Domestic Investments }} \\
\mu_{t}^{\mathrm{GDP}}
\end{array}\right]=\left[\begin{array}{cccc}
b_{11} & 0 & 0 & 0 \\
0 & b_{22} & 0 & 0 \\
0 & 0 & b_{33} & 0 \\
0 & 0 & 0 & b_{44}
\end{array}\right]\left[\begin{array}{c}
\varepsilon_{t}^{M \& A} \\
\varepsilon_{t}^{\text {Greenfield Investments }} \\
\varepsilon_{t}^{\text {Domestic Investments }} \\
\varepsilon_{t}^{\mathrm{GDP}}
\end{array}\right]
$$

As noted earlier, the order of variables will need to be specified based on relevant economic theories and consumption since the contemporaneous response of a variable to a shock of endogenous variables in this model depends highly on this order.

In the first instance, we assume that $M \& A$ is the most exogenous variable in the model and that it is likely to exert impacts on the other variables, but that it will not be affected by other endogenous variables in the model. Following the literature, we assume that M\&A could affect greenfield investments, as verified by Calderón et al. (2004), who proved that higher M\&As are followed by higher greenfield investments. M\&A and greenfield investments are therefore placed in the two first rows in the matrix.

Secondly, M\&A and greenfield investments would possibly crowd in or crowd out the domestic investments (Agosin and Machado 2005). This means that M\&A and greenfield investments could exert impacts on domestic investments and the response of domestic investments could either be negative or positive. Thus, domestic investments are placed in the third row.

Finally, in the last row of the matrix, we assume that economic growth responds contemporaneously to all shocks, although it has no contemporaneous effect on other variables. The conventional theory about the impact of foreign investment on growth (i.e. Solow 1956) paved the way for this assumption. In addition, domestic investment is a part of gross domestic product (GDP) and, therefore, affects economic growth. As such, and based on our assumptions, GDP seemed to be the least exogenous variable and it was placed in the last row of the matrix. ${ }^{3}$

\footnotetext{
3 To ensure the robustness of our empirical results, we conduct a robustness test in which the order of variables is changed. Specifically, the order of variables is now set as follows: GDP $\rightarrow$ GFCF $\rightarrow$ MA $\rightarrow$ GF. More information about the robustness test and its result is provided in Appendix A. Overall, the results are predominantly in line with the baseline results.
} 


\subsection{Data}

The focal point of this study is investigating the effects of greenfield investments and M\&As on both domestic investment and growth in Vietnam. Data on cross-border M\&As and greenfield investments are retrieved from UNCTAD's World Investment Report. Unfortunately, the available information on cross-border M\&A transactions and greenfield investments is limited prior to 1987 and 2003, respectively, while some earlier FDI entry mode studies (i.e. Calderón et al. 2004; Wang and Wong 2009; Eren and Zhuang 2015; Harms and Méon 2018) have simply calculated greenfield investments by subtracting M\&As from total FDI inflows that measurement of greenfield investment would not be a perfect proxy (i.e. correctly reflecting the actual value), because FDI inflow is an aggregation of both greenfield investment and M\&As, and also other similar capital transfer activities, such as reinvestments and disinvestments undertaken by multinational enterprises (MNEs). As a result, we do not use the self-constructed greenfield numbers, which are equal to the difference between FDI inflows and M\&As, during the missing period (from 1987 to 2002) because it can be an imperfect proxy. We therefore restrict the time window in our study to the 2003-to-2017 period, where data for both greenfield investments and M\&As are available.

With regard to the other variables, real GDP calculated at the constant 2010 US\$ price represents economic growth and it is drawn from the World Development Indicator provided by the World Bank. Domestic investment is measured by gross fixed capital formation, which is obtained from the General Statistics Office of Vietnam. It refers to expenditure for the investment in fixed assets, changes in inventories and precious items in a given period.

To span the series data, we follow the literature (i.e. Marcellino and Musso 2011; Grossman et al. 2014) and convert the annual data on M\&As, greenfield investments, domestic investment and economic growth into quarterly data using the quadratic match average method. Data are also transformed into logarithmic and differential forms to avoid possible heteroscedasticity and multicollinearity (Xu and Lin 2016).

\section{Empirical results}

This section evaluates the impacts of cross-border M\&As and greenfield investment on domestic investment and ultimately economic growth. Prior to that, a series of specification tests are conducted to ensure a well-specified model, and these include the stationary test, a co-integration test and lag length selection.

\subsection{Specification tests}

\subsubsection{Testing for stationary}

One problem that may be encountered with any time-series model is that the series data may be non-stationary. If this occurs, the regressions of non-stationary variables against other unrelated non-stationary variables in the model may lead to the 
spurious results (Phillips 1986). Following the literature, we use the standard unit root test to check the stationarity of the time series.

Augmented Dickey Fuller (ADF), Phillips Perron (PP) and Kwiatkowski Phillips Schmidt Shin (KPSS) are the three most common techniques for unit root testing. The ADF has been used widely in empirical studies, but this procedure incorporates auto-correlated and heteroscedastic non-systematic components, making the test vulnerable to inappropriate lag length specification (Hall 1994). In addition, the test may also lead to the biased results when time series contain a time trend (Xu and Lin 2016). The PP test, on the other hand, has advantages over the ADF tests by nonparametrically modifying the Dickey Fuller test statistics to allow for a very wide class of time-series models in which there is a unit root (Phillips and Perron 1988), and this makes the results robust to any serial correlation and heteroscedasticity (Chan et al. 1992). Consequently, the asymptotic distribution of the test statistic is not affected by the serial correlation, and the results do not depend on lag length selection either. However, both ADF and PP approaches may present bias towards the existence of unit roots in small-sample data such as ours (GomezBiscarri and Hualde 2015). In this context, KPSS appears to be a more appropriate method, as it is able to compensate for this limitation, as well as directly testing the null hypothesis of stationarity against the alternative of a unit root that ADF and PP attempt to check (Ajayi and Mougoue 1996). To this end, all three tests are used to ensure the credibility of the model.

The test results are shown in Table 1 . All variables are stationary at both level and first difference in the KPSS test, and they are stationary at first difference in the ADF and PP tests. To this end, although the tests do not indicate the identical results, all of the series can still be considered as stationary at first difference. Therefore, the precondition of the unit root test is met in order to proceed to the co-integration test.

Following the standard procedure in the previous literature, in the next step, we conduct the AR root test to check the stability of the SVAR model. This step is necessary because the model misspecification or parameter non-constancy may exert adverse consequences on statistical inferences and lead to misleading results (Xu and Lin 2016). Figure 1 shows that all characteristic roots are in the unit circle, meaning that the model is stable, and the result derived from the model is valid with the set of four variables.

\subsubsection{Testing for co-integration}

As economic series often experience stochastic trends or are non-stationary in their properties, the optimal way to reduce trends and avoid spurious regressions is to check for co-integration, which implies long-term relationships between variables. The reason for is that, when non-stationary variables are co-integrated, they will link together strongly and will not wander too far apart from each other, even when they have different stochastic trends (Phillips 1986). Following the literature, we conduct the commonly used Johansen approach to test for co-integration. In Table 2, both the trace test and the eigenvalue test indicate one vector of co-integration. Thus, it appears that there are long-term relationships between the variables in the study. 


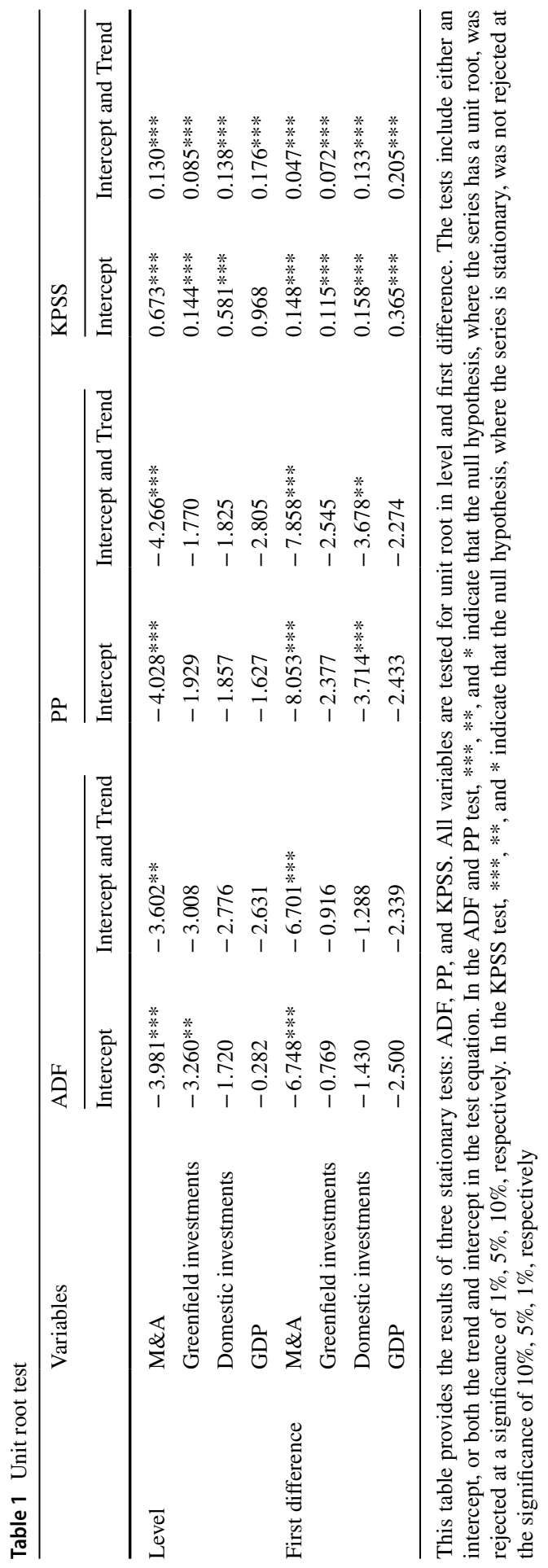


Fig. 1 Inverse roots of the characteristic AR polynomial. Note: This figure represents the inverse roots of the characteristic AR polynomial, which are indicated using blue dots

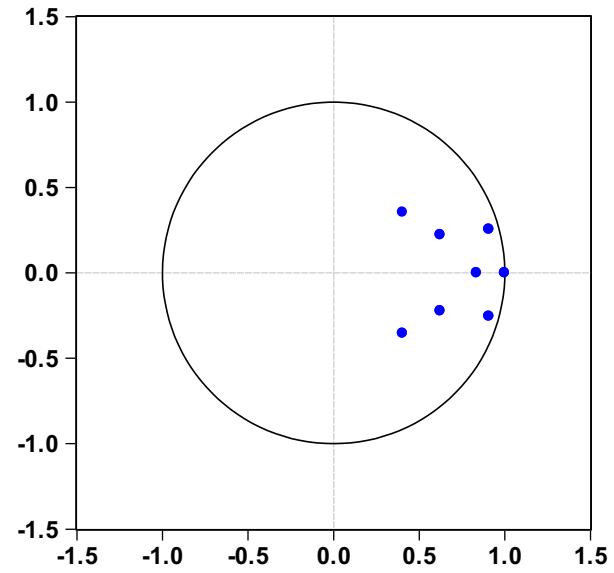

Table 2 Johansen co-integration test

\begin{tabular}{|c|c|c|c|c|}
\hline $\begin{array}{l}\text { Hypothesised no. of } \\
\text { CE(s) }\end{array}$ & Eigenvalue & Trace statistic & 0.05 Critical value & Prob.** \\
\hline None* & 0.4206 & 53.0904 & 47.8561 & 0.0149 \\
\hline At most 1 & 0.2155 & 21.9848 & 29.7971 & 0.2993 \\
\hline At most 2 & 0.1325 & 8.1492 & 15.4947 & 0.4496 \\
\hline At most 3 & 0.0008 & 0.0457 & 3.8415 & 0.8307 \\
\hline $\begin{array}{l}\text { Hypothesised No. } \\
\text { of CE(s) }\end{array}$ & Eigenvalue & Max-Eigen statistic & 0.05 Critical value & Prob.** \\
\hline None* & 0.4206 & 31.1056 & 27.5843 & 0.0169 \\
\hline At most 1 & 0.2155 & 13.8356 & 21.1316 & 0.3787 \\
\hline At most 2 & 0.1325 & 8.1035 & 14.2646 & 0.3683 \\
\hline At most 3 & 0.0008 & 0.0457 & 3.8415 & 0.8307 \\
\hline
\end{tabular}

This table provides the results of the trace test and the Max-eigenvalue test. Both indicate 1 co-integrating equation at the 0.05 level

*Rejection of the hypothesis at the $5 \%$ significant level

**Mackinnon-Haug-Michelis (1999) $p$ values

\subsubsection{Lag length selection}

According to $\mathrm{Xu}$ and Lin (2016), the inappropriate selection of lag structures can lead to an inefficient model. Specifically, if the lag period is too short, the data generating process will not be represented correctly, whereas if the lag period is too large, the model will face the problem of lacking degrees of freedom and the estimation will be unreliable (Song and Witt 2006). Thus, in order to ensure the appropriateness of the econometric models, and hence the empirical results, we follow the standard procedure in the literature (i.e. Xu and Lin 2016) and choose a lag of 2, as indicated by the sequential modified LR test statistic (LR), final prediction error 
Table 3 Lag selection criteria

\begin{tabular}{llllrrr}
\hline Lag & Log $L$ & LR & FPE & AIC & \multicolumn{1}{l}{ SC } & \multicolumn{1}{l}{ HQ } \\
\hline 0 & -50.4862 & NA & $7.69 \mathrm{e}-05$ & 1.878834 & 2.020933 & 1.934184 \\
1 & 402.5475 & 827.9580 & $2.20 \mathrm{e}-11$ & -13.19129 & -12.48079 & -12.91454 \\
2 & 462.8977 & $101.9712^{*}$ & $4.80 \mathrm{e}-12 *$ & $-14.72061 *$ & $-13.44172 *$ & $-14.22246^{*}$ \\
\hline
\end{tabular}

This table contains the results of the lag length selection tests based on the following criteria: LRsequential modified LR test statistic (each test is at the 5\% level); FPE-final prediction error; AICAkaike information criterion; SC-Schwarz information criterion; HQ-Hannan-Quinn information criterion

*Lag order selected by criterion

(FPE), Akaike information criterion (AIC), Schwarz information criterion (SC) and Hannan-Quinn information criterion (HQ) in Table 3.

\subsection{Impulse response function}

In this paper, we employ the impulse response function to analyse the empirical reaction of each endogenous variable in response to a standard deviation of different variables. This methodology is advantageous both for illustrating the dynamic linkages between the variables and also for identifying the shocks and measuring their effects on endogenous variables. The empirical results are reported in Fig. 2.

Figure 2a illustrates how domestic investment responds to a shock to cross-border M\&As. As demonstrated in this figure, domestic investment generally displays a negative response to M\&A shocks. Specifically, after continuously dropping steeply during the first half of each period, the impulse response of M\&A remains negative in both the mid- and the long-run. This indicates that cross-border M\&As generally hamper domestic investment. One potential explanation is that M\&As are only the transformation of the ownership of existing businesses, so they have almost no significant effect on domestic investment. This is consistent with the suggestion made by Agosin and Machado (2005) that foreign investment exerts no positive impact on domestic investment in developing countries. In the longer term, cross-border M\&As could lead to a sharp decrease in domestic investments as it could create higher entry barriers to domestic entrepreneurs and reduce their investment incentives (Danakol et al. 2017).

Panel 2B how domestic investment reacts spontaneously to a change of one standard deviation of greenfield investments. As demonstrated in Fig. 2b, greenfield investment facilitates domestic investment in Vietnam over time. This can be explained by the fact that the presence of foreign firms with superior technology and know-how may create positive spillover effects that are beneficial for domestic firms (Mileva 2008). Another explanation for the positive effect of greenfield investment on domestic investment is that the huge flow of greenfield investment into the host countries may also give rise to loanable funds, removing the financial constraints that domestic firms are facing and encouraging them to spend more on investments (Harrison et al. 2004). Empirically, this positive correlation between 
A

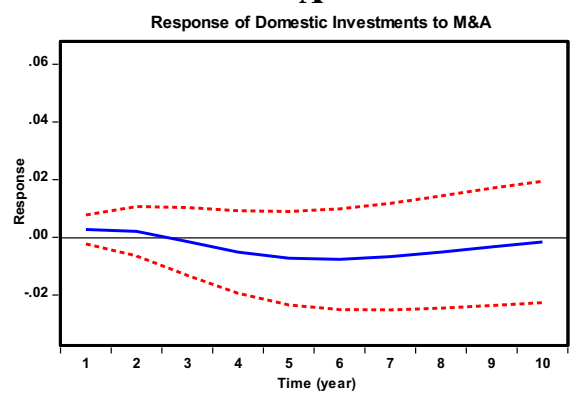

C

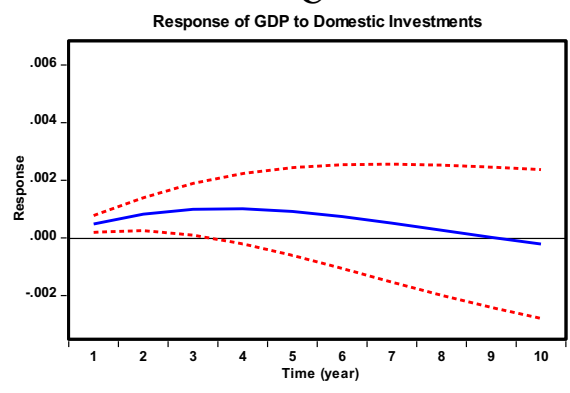

$\mathbf{E}$

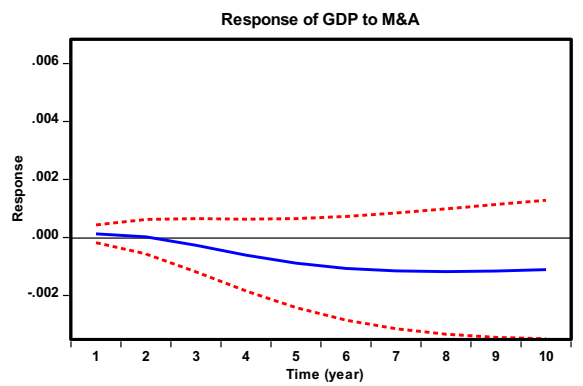

B

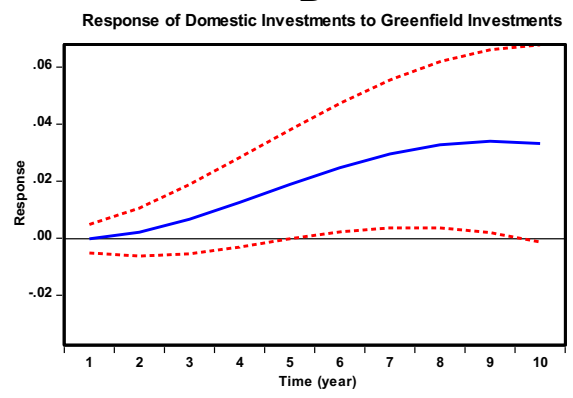

D

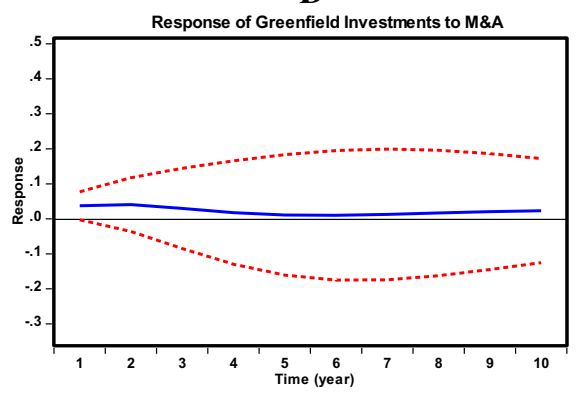

$\mathbf{F}$

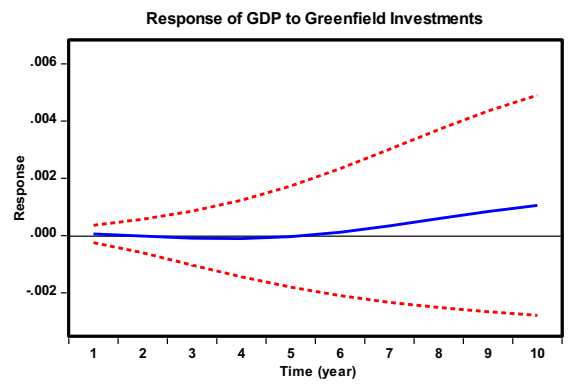

Fig. 2 Response of GDP and domestic investments to a shock to M\&A and greenfield investments. Note: The solid lines define the mean responses to one standard deviation, and the dotted lines represent \pm 2 standard deviations of these responses

inward foreign capital and domestic investment is also demonstrated in the study of Al-Sadig (2013).

Figure $2 \mathrm{c}$ provides an assessment of the response of economic growth to a structural shock of domestic investment. It is evident from this figure that domestic investments generate a positive effect on economic growth, which is shown by the positive response of economic growth to a shock to domestic investment mostly throughout the whole period. This result is consistent with the common perception that domestic investment can enhance economic growth via its direct contribution to the sum of a country's GDP. 
Figure $2 b$ uncovers the impact of a shock to M\&As on greenfield investment. As is being demonstrated in this figure, M\&A exerts a positive impact on greenfield investment. This impact is more pronounced in the first few years before becoming less obvious in the mid- and long-term. Overall, this result is consistent with the finding of Calderón et al. (2004) that M\&A leads to more greenfield investments in developing countries.

Figure 2e depicts the response of economic growth to a shock to cross-border M\&As. As can be seen in the figure, economic growth generally reacts negatively to a one standard deviation shock to M\&As, especially in the mid- and long-term. This finding illustrates that the Vietnamese economy may not benefit from attracting more foreign capital in the form of cross-border M\&As. Overall, this is also consistent with the existing literature, which criticises M\&As for just being speculative funds, seeking only the arbitrage profits with no value-adding contribution (i.e. Kim 2009). Therefore, they may not enhance the productivity of the host country.

Figure $2 \mathrm{f}$ describes how a structural shock of greenfield investment affects economic growth. In contrast to the effect shown in Fig. 2f, greenfield investments exert a positive effect on economic growth, especially in the long term. While the impact of greenfield investments on the economy is not quite clear in the first few years, the positive effect becomes more prominent in the subsequent period. A plausible explanation for this may be that since greenfield investments involve building everything from scratch, it may take a certain period of time for foreign investors to settle their business and start operating. Thus, the economic gains may not be realised immediately. As time passes, the host country can benefit from the contribution to fixed capital formation, enhancing employment and human resources, as well as the manufacturing exports from greenfield investors (i.e. Mencinger 2003).

Collectively, the estimated results illustrate that M\&As and greenfield investments have different impacts on domestic investment and economic growth in Vietnam. The findings of the study are largely consistent with the existing literature, which states that M\&As might be less beneficial than greenfield investments (Harms and Méon 2018; Wang and Wong 2009).

\subsection{Variance decomposition}

The variance decomposition shows how much of the forecast error variance of each variable can be explained by the shocks of other variables in the model. The variance decomposition for the twenty periods is selected to represent the short-term and long-term effects, as shown in Table 4 . As can be seen from the table, during the changes in growth, its own effect is $81.5 \%$ in the first period, but this then fluctuates over time. The GDP effect finally reaches approximately $86.8 \%$ in the last quarter. Subsequently, M\&A shocks are the second major contributor explaining GDP's variance. In the first year, they account for around $1.2 \%$ of the forecast error variance on average, although they increase to $17.1 \%$ in the long run. Domestic investment shock ranks third in its relative contribution. This impulse constitutes about $17 \%$ in the short-term, but decreases considerably before standing at just over $4.6 \%$ in 
Table 4 Variance decomposition of GDP

\begin{tabular}{llllll}
\hline Period & S.E. & M\&A & $\begin{array}{l}\text { Greenfield } \\
\text { investments }\end{array}$ & Domestic investment & GDP \\
\hline 1 & 0.001169 & 1.200616 & 0.222297 & 17.1035 & 81.47359 \\
2 & 0.002302 & 0.320641 & 0.062437 & 17.17757 & 82.43935 \\
3 & 0.003465 & 0.747777 & 0.095739 & 15.7679 & 83.38859 \\
4 & 0.004634 & 2.146197 & 0.105859 & 13.58172 & 84.16623 \\
5 & 0.005786 & 3.730247 & 0.071917 & 11.21552 & 84.98231 \\
6 & 0.0069 & 5.015578 & 0.079954 & 9.031944 & 85.87252 \\
7 & 0.007959 & 5.874103 & 0.241621 & 7.199063 & 86.68521 \\
8 & 0.00896 & 6.358709 & 0.629091 & 5.767825 & 87.24437 \\
9 & 0.0099 & 6.571279 & 1.241 & 4.725115 & 87.46261 \\
10 & 0.010778 & 6.6056 & 2.004582 & 4.024939 & 87.36488 \\
11 & 0.011597 & 6.532299 & 2.80462 & 3.60792 & 87.05516 \\
12 & 0.012355 & 6.399704 & 3.521315 & 3.413436 & 86.66555 \\
13 & 0.013056 & 6.238659 & 4.061654 & 3.386001 & 86.31369 \\
14 & 0.013705 & 6.067295 & 4.37701 & 3.477473 & 86.07822 \\
15 & 0.014309 & 5.894941 & 4.46666 & 3.646897 & 85.9915 \\
16 & 0.014881 & 5.725269 & 4.370224 & 3.859596 & 86.04491 \\
17 & 0.015433 & 5.558855 & 4.152865 & 4.08653 & 86.20175 \\
18 & 0.015978 & 5.395209 & 3.887266 & 4.304294 & 86.41323 \\
19 & 0.016527 & 5.234205 & 3.636622 & 4.495597 & 86.63358 \\
20 & 0.017088 & 5.076823 & 3.442628 & 4.649699 & 86.83085 \\
\hline
\end{tabular}

This table represents the percentage of the forecast error variance of GDP, as explained by the other variables over 20 periods

the long-term. Racing with domestic investments is greenfield investments, which account for approximately $3.4 \%$ of the long-term fluctuation in GDP.

Although there is a steady drop in the contributed proportion, the changes in domestic investment are predominantly explained by themselves during the estimated period (Table 5). Specifically, it falls sharply from roughly $98 \%$ in the short run to around $28 \%$ in the long run. Greenfield investment shares the second largest part of the forecast error variance in domestic investment, followed by GDP shock in the third place. M\&As explain around $2 \%$ of the variation in both the short- and the long-term. While the influence of greenfield investments contributes to the forecast error variance in domestic investment significantly, the other entry mode of FDI does not give a remarkably explanatory power to the fluctuation in domestic investment.

The corresponding importance of the different driving forces of M\&A can be assessed by investigating the decomposition of their forecast error variance, as illustrated in Table 6. M\&A itself explains $100 \%$ of its own forecast error variance in the short run, but this effect decreases gradually and hits $78 \%$ in the last period, remaining the most crucial factor. Next, shock to greenfield investments ranks second and 
Table 5 Variance decomposition of domestic investments

\begin{tabular}{|c|c|c|c|c|c|}
\hline Period & S.E. & M\&A & $\begin{array}{l}\text { Greenfield } \\
\text { investments }\end{array}$ & Domestic investments & GDP \\
\hline 1 & 0.019258 & 1.99011 & 0.008694 & 98.0012 & 0 \\
\hline 2 & 0.03325 & 1.053039 & 0.406848 & 98.52333 & 0.016786 \\
\hline 3 & 0.044309 & 0.69919 & 2.505067 & 96.72741 & 0.068334 \\
\hline 4 & 0.053482 & 1.392133 & 7.250432 & 91.18823 & 0.169207 \\
\hline 5 & 0.061758 & 2.425733 & 14.76367 & 82.45657 & 0.354035 \\
\hline 6 & 0.069753 & 3.097296 & 24.14908 & 72.07173 & 0.681896 \\
\hline 7 & 0.077731 & 3.237174 & 33.88556 & 61.65763 & 1.219639 \\
\hline 8 & 0.085625 & 3.023587 & 42.54313 & 52.42091 & 2.012374 \\
\hline 9 & 0.093124 & 2.683579 & 49.29707 & 44.95507 & 3.064281 \\
\hline 10 & 0.099829 & 2.361572 & 53.96625 & 39.33229 & 4.339896 \\
\hline 11 & 0.105407 & 2.118435 & 56.77343 & 35.333 & 5.775136 \\
\hline 12 & 0.10968 & 1.966361 & 58.10827 & 32.63916 & 7.286207 \\
\hline 13 & 0.112663 & 1.895532 & 58.39557 & 30.93433 & 8.774569 \\
\hline 14 & 0.114538 & 1.887206 & 58.04438 & 29.93565 & 10.13276 \\
\hline 15 & 0.115602 & 1.919042 & 57.4278 & 29.39635 & 11.2568 \\
\hline 16 & 0.116195 & 1.968004 & 56.85947 & 29.10531 & 12.06721 \\
\hline 17 & 0.116628 & 2.013565 & 56.55858 & 28.8946 & 12.53325 \\
\hline 18 & 0.117121 & 2.041378 & 56.61839 & 28.65261 & 12.68763 \\
\hline 19 & 0.117783 & 2.045818 & 57.0028 & 28.3317 & 12.61968 \\
\hline 20 & 0.11861 & 2.029826 & 57.58254 & 27.94083 & 12.4468 \\
\hline
\end{tabular}

This table represents the percentage of the forecast error variance of domestic investments, as explained by the other variables over 20 periods

causes roughly $9.1 \%$ fluctuation in M\&A. GDP and investment explain around $8 \%$ and $5 \%$ of the variation in M\&A, respectively.

As demonstrated in Table 7, GDP is the second most important variable explaining greenfield investments' forecast error variance following greenfield investment itself. GDP makes up $0 \%$ of the variability in the first quarter. Throughout the period, moderate increases to $21 \%$ are recorded in the contribution from GDP to greenfield investments' variance. Both innovation in domestic investment and M\&A have little influence on the fluctuation of greenfield investments in the short run as well as in the long run, as it stays at around $1 \%$.

\section{Conclusion}

What is the impact of FDI on economic growth? Why do some studies suggest that FDI is an important element that fosters economic growth, whereas others document a negative FDI-growth nexus, thus suggesting that policies to promote domestic investment over foreign capital are necessary? This paper attempts to 
Table 6 Variance decomposition of M\&A

\begin{tabular}{|c|c|c|c|c|c|}
\hline Period & S.E. & M\&A & $\begin{array}{l}\text { Greenfield } \\
\text { investments }\end{array}$ & Domestic investment & GDP \\
\hline 1 & 0.542288 & 100 & 0 & 0 & 0 \\
\hline 2 & 0.735512 & 99.20965 & 0.20523 & 0.000943 & 0.584179 \\
\hline 3 & 0.790951 & 97.42794 & 0.361191 & 0.185373 & 2.025493 \\
\hline 4 & 0.805978 & 94.98802 & 0.348896 & 1.013603 & 3.64948 \\
\hline 5 & 0.817786 & 92.27378 & 0.544073 & 2.509137 & 4.673006 \\
\hline 6 & 0.830586 & 89.65849 & 1.149957 & 4.183125 & 5.008428 \\
\hline 7 & 0.84179 & 87.49306 & 1.910341 & 5.609863 & 4.986733 \\
\hline 8 & 0.849881 & 85.97111 & 2.477879 & 6.65594 & 4.895066 \\
\hline 9 & 0.854888 & 85.0603 & 2.718012 & 7.367113 & 4.854572 \\
\hline 10 & 0.857764 & 84.5653 & 2.733815 & 7.830466 & 4.870421 \\
\hline 11 & 0.859778 & 84.23385 & 2.74909 & 8.114693 & 4.902364 \\
\hline 12 & 0.862043 & 83.84557 & 2.977613 & 8.26437 & 4.912444 \\
\hline 13 & 0.865241 & 83.26736 & 3.534373 & 8.311158 & 4.887104 \\
\hline 14 & 0.869542 & 82.47174 & 4.406009 & 8.283368 & 4.838883 \\
\hline 15 & 0.874676 & 81.52017 & 5.475472 & 8.20917 & 4.795188 \\
\hline 16 & 0.880099 & 80.52359 & 6.578231 & 8.114988 & 4.783194 \\
\hline 17 & 0.885204 & 79.59836 & 7.560825 & 8.022329 & 4.818483 \\
\hline 18 & 0.889492 & 78.83291 & 8.320796 & 7.945473 & 4.90082 \\
\hline 19 & 0.892688 & 78.27112 & 8.821583 & 7.890964 & 5.016335 \\
\hline 20 & 0.894772 & 77.91116 & 9.08671 & 7.85867 & 5.143465 \\
\hline
\end{tabular}

This table represents the percentage of the forecast error variance of M\&A, as explained by the other variables over 20 periods

shed light on this paradox by examining different aspects of FDI. In particular, we do not consider the aggregated FDI level as a homogenous factor that may affect the host country's economy. Instead, we break down the aggregated FDI level that a country receives into its major components: greenfield investment and cross-border M\&As. We argue that, since greenfield investment and crossborder M\&As are distinct in their nature, they may have different impacts on the economy.

To this end, we examine the dynamic relationship between greenfield investments, cross-border M\&A, domestic investment and economic growth in Vietnam over the period from 2003 to 2017. The empirical results show that, while greenfield investments complement domestic investment, which subsequently leads to higher economic growth, cross-border M\&As exert a significant crowd-out effect and thus hamper the economy over both the short- and long-term.

Overall, our study emphasises the importance to policy makers and academic researchers in making a closer inspection on the economic implications of different components of FDI. Considering FDI as a homogenous factor when assessing its economic implications may be erroneous and could subsequently lead to 
Table 7 Variance decomposition of greenfield investments

\begin{tabular}{|c|c|c|c|c|c|}
\hline Period & S.E. & M\&A & $\begin{array}{l}\text { Greenfield } \\
\text { investments }\end{array}$ & Domestic investments & GDP \\
\hline 1 & 0.1551 & 5.77161 & 94.22839 & 0 & 0 \\
\hline 2 & 0.298503 & 3.415835 & 95.50084 & 0.206405 & 0.876919 \\
\hline 3 & 0.432933 & 2.093783 & 94.73177 & 0.503344 & 2.671101 \\
\hline 4 & 0.549966 & 1.403016 & 92.88527 & 0.743317 & 4.9684 \\
\hline 5 & 0.645757 & 1.047308 & 90.54677 & 0.885007 & 7.520911 \\
\hline 6 & 0.719671 & 0.862419 & 88.0226 & 0.941339 & 10.17365 \\
\hline 7 & 0.773305 & 0.773356 & 85.474 & 0.944286 & 12.80836 \\
\hline 8 & 0.809677 & 0.747924 & 83.01806 & 0.924261 & 15.30975 \\
\hline 9 & 0.832583 & 0.768511 & 80.77749 & 0.901288 & 17.55271 \\
\hline 10 & 0.84608 & 0.819518 & 78.88723 & 0.884116 & 19.40913 \\
\hline 11 & 0.853999 & 0.883982 & 77.46944 & 0.873599 & 20.77298 \\
\hline 12 & 0.85951 & 0.945123 & 76.59212 & 0.867408 & 21.59535 \\
\hline 13 & 0.864797 & 0.99 & 76.23491 & 0.863891 & 21.9112 \\
\hline 14 & 0.870933 & 1.012692 & 76.28596 & 0.863798 & 21.83754 \\
\hline 15 & 0.878012 & 1.01494 & 76.57635 & 0.86975 & 21.53896 \\
\hline 16 & 0.885465 & 1.003921 & 76.93366 & 0.88449 & 21.17793 \\
\hline 17 & 0.892474 & 0.988639 & 77.22728 & 0.909253 & 20.87482 \\
\hline 18 & 0.898319 & 0.976734 & 77.3891 & 0.943031 & 20.69113 \\
\hline 19 & 0.902603 & 0.97271 & 77.41071 & 0.982755 & 20.63382 \\
\hline 20 & 0.905322 & 0.977562 & 77.32666 & 1.02407 & 20.67171 \\
\hline
\end{tabular}

This table represents the percentage of the forecast error variance of Greenfield Investments, as explained by the other variables over 20 periods

inappropriate policy implications. As greenfield investment seems to indicate a more beneficial FDI entry mode rather than M\&A in Vietnam, there is a need for the Vietnamese government to provide policy incentives to attract more greenfield investment. Moreover, as these positive effects might be distributed unequally among the economic sectors in Vietnam, there is a need from the government to improve infrastructure and governance ( $\mathrm{Vu}$ et al. 2008), in order to support the less-developed economic sectors, such as the transportation and construction sectors, through further encouragement of inward Greenfields investments flow. Meanwhile, since cross-border M\&A appears to exhibit a detrimental effect on domestic investment, and subsequently on economic growth, policies which aim to reduce the crowding-out impact of M\&A could be desirable. More restrictions may also be imposed on foreign investors to lessen their huge M\&A flow into some sectors in which domestic firms have either limited comparative advantages or even none at all, especially in the manufacturing industry (Le 2010). 
A

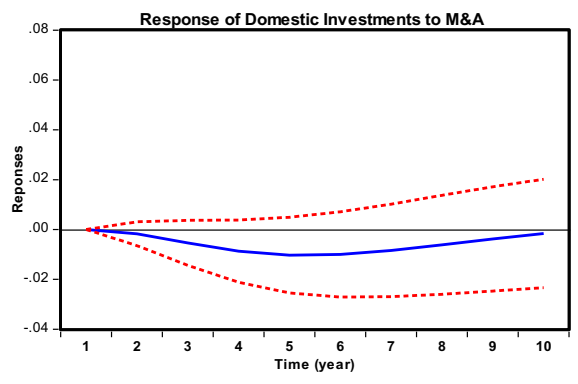

C

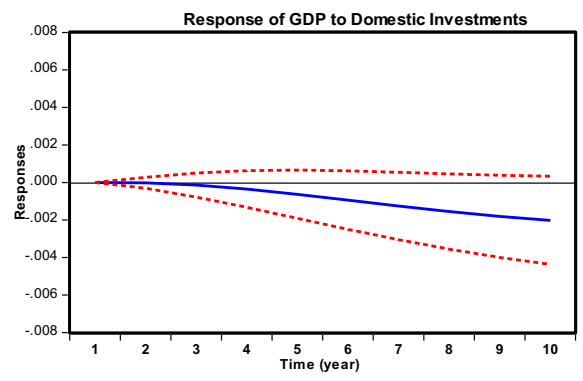

E

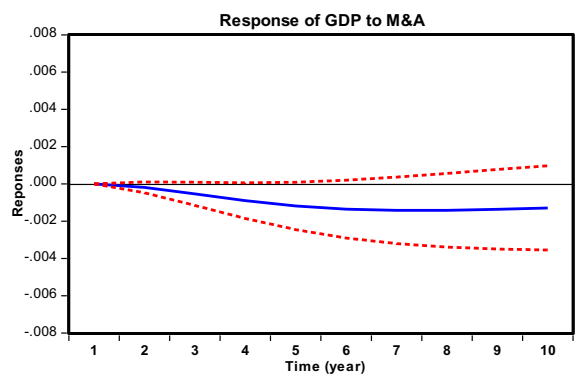

B

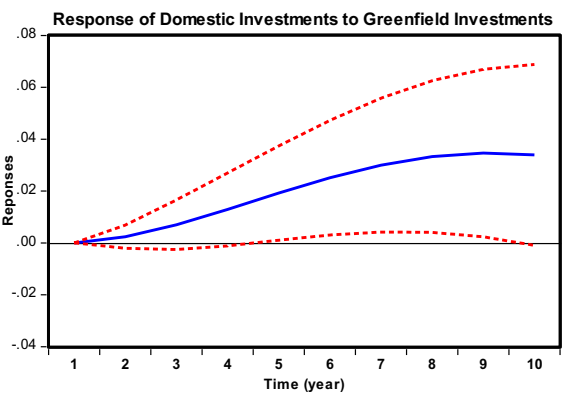

D

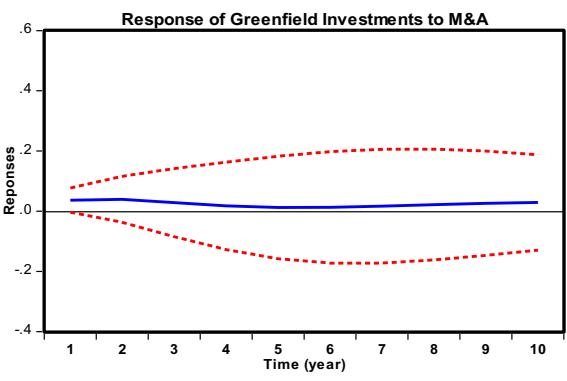

$\mathbf{F}$

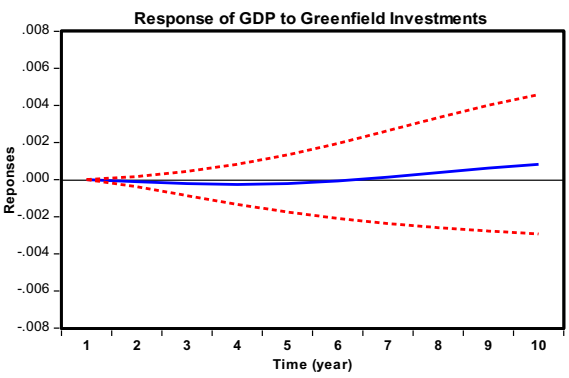

Fig. 3 Response of M\&A and greenfield investments to a shock to GDP and domestic investment

Acknowledgements This research is funded by Vietnam National Foundation for Science and Technology Development (NAFOSTED) under Grant No. 502.02-2020.09.

\section{Compliance with ethical standards}

Conflict of interest The authors declare that there is no conflict of interest regarding the publication of this article. 
Open Access This article is licensed under a Creative Commons Attribution 4.0 International License, which permits use, sharing, adaptation, distribution and reproduction in any medium or format, as long as you give appropriate credit to the original author(s) and the source, provide a link to the Creative Commons licence, and indicate if changes were made. The images or other third party material in this article are included in the article's Creative Commons licence, unless indicated otherwise in a credit line to the material. If material is not included in the article's Creative Commons licence and your intended use is not permitted by statutory regulation or exceeds the permitted use, you will need to obtain permission directly from the copyright holder. To view a copy of this licence, visit http://creativecommons.org/licen ses/by/4.0/.

\section{Appendix: Robustness test: alternative order of variables}

In this robustness test, we assume that economic growth is the most exogenous variable in the model and that it is likely to impact on the other variables. This is because the economic condition in a certain country could affect the investment incentives of investors directly, both domestic and overseas. Previous researches also contend that domestic investment may impact on the investment incentive of foreign investors, as it can serve as an indication of how thriving and competitive the market is. Therefore, it follows GDP and is placed in the second row of the matrix.

Arguably, foreign investors consider the cost-benefit trade-off associated with various aspects of host countries' social-economic environments when making their penetration strategies. Since both the economic condition and domestic investment level are parts of the host country's overall economic environment, it is reasonable to assume that both M\&A and greenfield investment will be influenced by the host country's GDP and investment level. Following the literature, we assume that M\&A could affect greenfield investments. This assumption is based on the proposition of Calderón et al. (2004) that higher M\&As are followed by higher greenfield investments. Thus, M\&A is placed in the third row of the matrix, whereas greenfield investment is placed in the last row. To this end, our matrix is specified as follows:

$$
\left[\begin{array}{cccc}
1 & 0 & 0 & 0 \\
a_{21} & 1 & 0 & 0 \\
a_{31} & a_{32} & 1 & 0 \\
a_{41} & a_{42} & a_{43} & 1
\end{array}\right]\left[\begin{array}{c}
\mu_{t}^{\mathrm{GDP}} \\
\mu_{t}^{\text {Domestic Investments }} \\
\mu_{t}^{\mathrm{MA}} \\
\mu_{t}^{\text {Greenfield Investments }}
\end{array}\right]=\left[\begin{array}{cccc}
b_{11} & 0 & 0 & 0 \\
0 & b_{22} & 0 & 0 \\
0 & 0 & b_{33} & 0 \\
0 & 0 & 0 & b_{44}
\end{array}\right]\left[\begin{array}{c}
\varepsilon_{t}^{\mathrm{GDP}} \\
\varepsilon_{t}^{\text {Domestic Investments }} \\
\varepsilon_{t}^{\mathrm{MA}} \\
\varepsilon_{t}^{\text {Greenfield Investments }}
\end{array}\right]
$$

The empirical results are reported in Fig. 3. Overall, the results are predominantly in line with the baseline results reported earlier. ${ }^{4}$

\footnotetext{
4 A series of specification tests, including the stationary test, co-integration test, and lag length selection are also conducted to ensure a well-specified model. Our model passes all of these tests.
} 


\section{References}

Abu N, Karim MZA (2016) The relationships between foreign direct investment, domestic savings, domestic investment, and economic growth: the case of Sub-Saharan Africa. Soc Econ Central Eastern Europe 38(2):193-217

Adams S (2009) Foreign direct investment, domestic investment, and economic growth in Sub-Saharan Africa. J Policy Model 31(6):939-949

Agosin MR, Machado R (2005) Foreign investment in developing countries: does it crowd in domestic investment? Oxf Dev Stud 33(2):149-162

Ahmad N, Hdia M, Li HZ, Wang J, Tian XL (2018) Foreign investment, domestic investment and economic growth in china: Does foreign investment crowd in or crowd out domestic investment? Econ Bull 38(3):1279-1291

Aitken BJ, Harrison AE (1999) Do domestic firms benefit from direct foreign investment? Evidence from Venezuela. Am Econ Rev 89(3):605-618

Ajayi RA, Mougouė M (1996) On the dynamic relation between stock prices and exchange rates. J Financ Res 19(2):193-207

Alfaro L, Chanda A, Kalemli-Ozcan S, Sayek S (2004) FDI and economic growth: the role of local financial markets. J Int Econ 64(1):89-112

Al-Sadig A (2013) The effects of foreign direct investment on private domestic investment: evidence from developing countries. Empir Econ 44(3):1267-1275

Anwar S, Nguyen LP (2010) Foreign direct investment and economic growth in Vietnam. Asia Pac Bus Rev 16(1-2):183-202

Ashraf A, Herzer D (2014) The effects of greenfield investment and M\&As on domestic investment in developing countries. Appl Econ Lett 21(14):997-1000

Ashraf A, Herzer D, Nunnenkamp P (2016) The effects of Greenfield FDI and cross-border M\&As on total factor productivity. World Econ 39(11):1728-1755

Azman-Saini WNW, Law SH, Ahmad AH (2010) FDI and economic growth: new evidence on the role of financial markets. Econ Lett 107(2):211-213

Balsvik R, Haller SA (2010) Foreign firms and host-country productivity: does the mode of entry matter? Oxf Econ Pap 63(1):158-186

Blomström M (1991) Host country benefits of foreign investment (No. w3615). National Bureau of Economic Research, Cambridge

Blomström M, Sjöholm F (1999) Technology transfer and spillovers: Does local participation with multinationals matter? European Economic Review 43(46):915-923

Calderón C, Loayza N, Servén L (2004) Greenfield foreign direct investment and mergers and acquisitions: Feedback and macroeconomic effects. The World Bank, Singapore

Caves RE (1974) Multinational firms, competition, and productivity in host-country markets. Economica 41(162):176-193

Chan KC, Gup BE, Pan MS (1992) An empirical analysis of stock prices in major Asian markets and the United States. Financ Rev 27(2):289-307

Chen GS, Yao Y, Malizard J (2017) Does foreign direct investment crowd in or crowd out private domestic investment in China? The effect of entry mode. Econ Model 61:409-419

Danakol SH, Estrin S, Reynolds P, Weitzel U (2017) Foreign direct investment via M\&A and domestic entrepreneurship: blessing or curse? Small Bus Econ 48(3):599-612

De Mello Jr LR (1997) Foreign direct investment in developing countries and growth: a selective survey. J Dev Stud 34(1):1-34

Desbordes R, Franssen L (2019) Foreign direct investment and productivity: a cross-country, multisector analysis. Asian Dev Rev 36(1):54-79

Driffield N, Hughes D (2003) Foreign and domestic investment: regional development or crowding out? Reg Stud 37(3):277-288

Durham JB (2004) Absorptive capacity and the effects of foreign direct investment and equity foreign portfolio investment on economic growth. Eur Econ Rev 48(2):285-306

Eren M, Zhuang H (2015) Mergers and acquisitions versus greenfield investment, absorptive capacity, and economic growth: evidence from 12 new member states of the European Union. Eastern Eur Econ 53(2):99-123

Farla K, De Crombrugghe D, Verspagen B (2016) Institutions, foreign direct investment, and domestic investment: crowding out or crowding in? World Dev 88:1-9 
Firebaugh G (1992) Growth effects of foreign and domestic investment. Am J Sociol 98(1):105-130

Fischer S (1993) The role of macroeconomic factors in growth. J Monet Econ 32(3):485-512

Gomez-Biscarri J, Hualde J (2015) A residual-based ADF test for stationary cointegration in I (2) settings. J Econom 184(2):280-294

Görg H, Greenaway D (2004) Much ado about nothing? Do domestic firms really benefit from foreign direct investment? World Bank Res Obs 19(2):171-197

Grossman GM, Helpman E (1991) Innovation and growth in the global economy. MIT Press, Cambridge

Grossman V, Mack A, Martinez-Garcia E (2014) A new database of global economic indicators. J Econ Soc Measur 39(3):163-197

Gunby P, Jin Y, Reed WR (2017) Did FDI really cause Chinese economic growth? A meta-analysis. World Dev 90:242-255

Hall A (1994) Testing for a unit root in time series with pretest data-based model selection. J Bus Econ Stat 12(4):461-470

Harms P, Méon PG (2018) Good and useless FDI: the growth effects of greenfield investment and mergers and acquisitions. Rev Int Econ 26(1):37-59

Harrison AE, Love I, McMillan MS (2004) Global capital flows and financing constraints. J Dev Econ 75(1):269-301

Hayat A (2018) FDI and economic growth: the role of natural resources? J Econ Stud 45(2):283-295

Herzer D, Klasen S (2008) In search of FDI-led growth in developing countries: the way forward. Econ Model 25(5):793-810

Hoang TT, Wiboonchutikula P, Tubtimtong B (2010) Does foreign direct investment promote economic growth in Vietnam? ASEAN Econ Bull 27:295-311

Jude C (2018) Does FDI crowd out domestic investment in transition countries? Econ Trans Inst Change 27(1):163-200

Kim YH (2009) Cross-border M\&A vs. greenfield FDI: economic integration and its welfare impact. J Policy Model 31(1):87-101

Le QP (2010) Evaluating Vietnam's changing comparative advantage patterns. ASEAN Econ Bull 27:221-230

Lee J, Yue C (2017) Impacts of the US dollar (USD) exchange rate on economic growth and the environment in the United States. Energy Econ 64:170-176

Levchenko AA, Mauro P (2007) Do some forms of financial flows help protect against "sudden stops"? World Bank Econ Rev 21(3):389-411

Liu X, Zou H (2008) The impact of greenfield FDI and mergers and acquisitions on innovation in Chinese high-tech industries. J World Bus 43(3):352-364

Lucas R (1988) On the mechanics of development planning. J Monet Econ 22(1):3-42

Magkonis G, Tsopanakis A (2014) Exploring the effects of financial and fiscal vulnerabilities on G7 economies: evidence from SVAR analysis. J Int Financ Mark Inst Money 32:343-367

Makiela K, Ouattara B (2018) Foreign direct investment and economic growth: exploring the transmission channels. Econ Model 72:296-305

Marcellino M, Musso A (2011) The reliability of real-time estimates of the euro area output gap. Econ Model 28(4):1842-1856

Mencinger J (2003) Does foreign direct investment always enhance economic growth? Kyklos 56(4):491-508

Mileva E (2008) The impact of capital flows on domestic investment in transition economies. ECB working paper no. 871

Mutenyo J, Asmah E (2010) Does foreign direct investment crowd-out domestic private investment in Sub-Saharan Africa? Afric Finance J 12(1):27-52

Navaretti GB, Venables AJ, Barry F (2006) Multinational firms in the world economy. Princeton University Press, Princeton

Ndikumana L, Verick S (2008) The linkages between FDI and domestic investment: unravelling the developmental impact of foreign investment in Sub-Saharan Africa. Dev Policy Rev 26(6):713-726

Nguyen CD, Simpson G, Saal D, Nguyen AN, Pham NQ (2008) FDI horizontal and vertical effects on local firm technical efficiency. Development and Policies Research Center of Vietnam, working paper

Omri A, Kahouli B (2014) The nexus among foreign investment, domestic capital and economic growth: empirical evidence from the MENA region. Res Econ 68(3):257-263

Phillips PC (1986) Understanding spurious regressions in econometrics. J Econom 33(3):311-340

Phillips PC, Perron P (1988) Testing for a unit root in time series regression. Biometrika 75(2):335-346 
Rodriguez-Clare A (1996) Multinationals, linkages, and economic development. Am Econ Rev $86: 852-873$

Romer PM (1986) Increasing returns and long-run growth. J Polit Econ 94(5):1002-1037

Smarzynska Javorcik B (2004) Does foreign direct investment increase the productivity of domestic firms? In search of spillovers through backward linkages. Am Econ Rev 94(3):605-627

Solow RM (1956) A contribution to the theory of economic growth. Q J Econ 70(1):65-94

Song H, Witt SF (2006) Forecasting international tourist flows to Macau. Tour Manag 27(2):214-224

Tang S, Selvanathan EA, Selvanathan S (2008) Foreign direct investment, domestic investment and economic growth in China: a time series analysis. World Econ 31(10):1292-1309

Thoburn J (2013) Vietnam as a role model for development. In: Fosu AK (ed) Achieving development success: strategies and lessons from the developing world. Oxford University Press, Oxford

Tong H, Wei SJ (2011) The composition matters: capital inflows and liquidity crunch during a global economic crisis. The Review of Financial Studies 24(6):2023-2052

UNCTAD (2000) World investment report 2000: Cross-border mergers and acquisitions and development. New York

Vu TB (2008) Foreign direct investment and endogenous growth in Vietnam. Appl Econ 40(9):1165-1173

Vu TB, Gangnes B, Noy I (2008) Is foreign direct investment good for growth? Evidence from sectoral analysis of China and Vietnam. J Asia Pac Econ 13(4):542-562

Wang M, Sunny Wong MC (2009) What drives economic growth? The case of cross-border M\&A and greenfield FDI activities. Kyklos 62(2):316-330

Xu B, Lin B (2016) Assessing CO2 emissions in China's iron and steel industry: a dynamic vector autoregression model. Appl Energy 161:375-386

Zeng S, Nan X, Liu C, Chen J (2017) The response of the Beijing carbon emissions allowance price (BJC) to macroeconomic and energy price indices. Energy Policy 106:111-121

Publisher's Note Springer Nature remains neutral with regard to jurisdictional claims in published maps and institutional affiliations. 